\title{
SISTEM INFORMASI HASIL PANEN PADI KABUPATEN SUBANG BERBASIS WEB
}

\author{
Ade Supriatna \\ Program Studi Teknik Informatika, STMIK Subang \\ E-mail: adespr69@gmail.com
}

\begin{abstract}
Abstrak
Produksi dan produktivitas padi di kabupaten Subang harus dapat diinformasikan oleh Dinas Pertanian secara mudah sesuai dengan kemajuan teknologi informasi dan internet. Penelitian ini tentang data dan informasi yang terintegrasi terhadap sistem berbasis komputer (computer based information system) terkait hasil panen komoditas tanaman padi. Laporan hasil panen padi berbasis komputer dimaksudkan untuk mempermudah dalam menginputkan data-data yang bersumber dari daerah subang secara online. Kemudian dari sisi user (masyarakat) akan terbantu semakin praktis dan mudah dalam mendapatkan informasi. Dan pelayanan pada dinas pertanian subang tidak selalu harus langsung di kantor melainkan dapat dilakukan secara online. Dengan begitu proses laporannya, cepat dan terstruktur.

Pembuatan laporan yang semula masih bersifat manual yaitu dengan cara melakukan rekapitulasi transaksi yang berbasis kertas kemudian beralih ke penerapan teknologi komputer yang berbasis web dan metode penelitian adalah kuantitatif.
\end{abstract}

Kata kunci : dinas pertanian, sistem informasi, produksi padi, web-based, penelitian kuantitatif

Abstract
Rice production and productivity in Subang district must be easily informed by the Department of Agriculture in accordance with advances in information technology and the internet. This study is about data and information that is integrated into a computer-based information system related to the yield of rice crops. The computer-based rice yield report is intended to make it easier to enter data sourced from the corm area online. Then from the user (community) side it will be more practical and easier to get information. And services at the subang agriculture service do not always have to be directly in the office but can be done online. That way the reporting process, fast and structured.

Reporting, which was originally still manual, was to recapitulate paper-based transactions and then switch to the application of web-based computer technology and the research method was quantitative.

Keywords: agriculture department, information systems, rice production, web-based, quantitative research

\section{Pendahuluan}

Teknologi informasi merupakan tulang punggung dalam pengolahan data dan informasi yang sangat penting bagi suatu perusahaan/ instansi dalam skala kecil, skala sedang ataupun skala besar. Sehingga informasi yang diharapkan dapat mempermudah dan memperlancar pekerjaan/ kegiatan serta tujuannya yang dapat dicapai secara optimal. Hal ini perlu dilakukan secara komputerisasi dalam pengumpulan, pengolahan dan penyimpanan data-data perusahaan /instansi tersebut. Sehingga dalam penyajian informasi data dapat dilakukan secara baik.

Dinas Pertanian Kab.Subang yang berkedudukan di Jl. Aipda KS Tubun No.7, Cigadung, Kecamatan Subang, Kabupaten Subang, Jawa Barat adalah salah satu dinas yang memiliki data dan informasi pertanian seperti luas baku lahan, luas tanam, luas panen, produktivitas dan produksi serta data lainnya yang dianggap penting oleh pemakai data dalam membuat perencanaan dan pengambilan keputusan. Berdasarkan temuan permasalahan yakni belum ada informasi secara substansi tentang produksi tanaman padi. Pengumpulan informasi substansi komoditi pertanian tidak termasuk di situs utama, atau tidak ada link ke situs pendukung. Yang ada malah secara 
terpisah informasi produksi tanaman padi ada di situs badan pusat statistik kabupaten subang. Berdasarkan permasalahan tersebut maka diperlukan suatu program aplikasi yang dapat mempermudah dalam penyampaian informasi produksi padi untuk menjadi informasi yang dimuat dalam website.

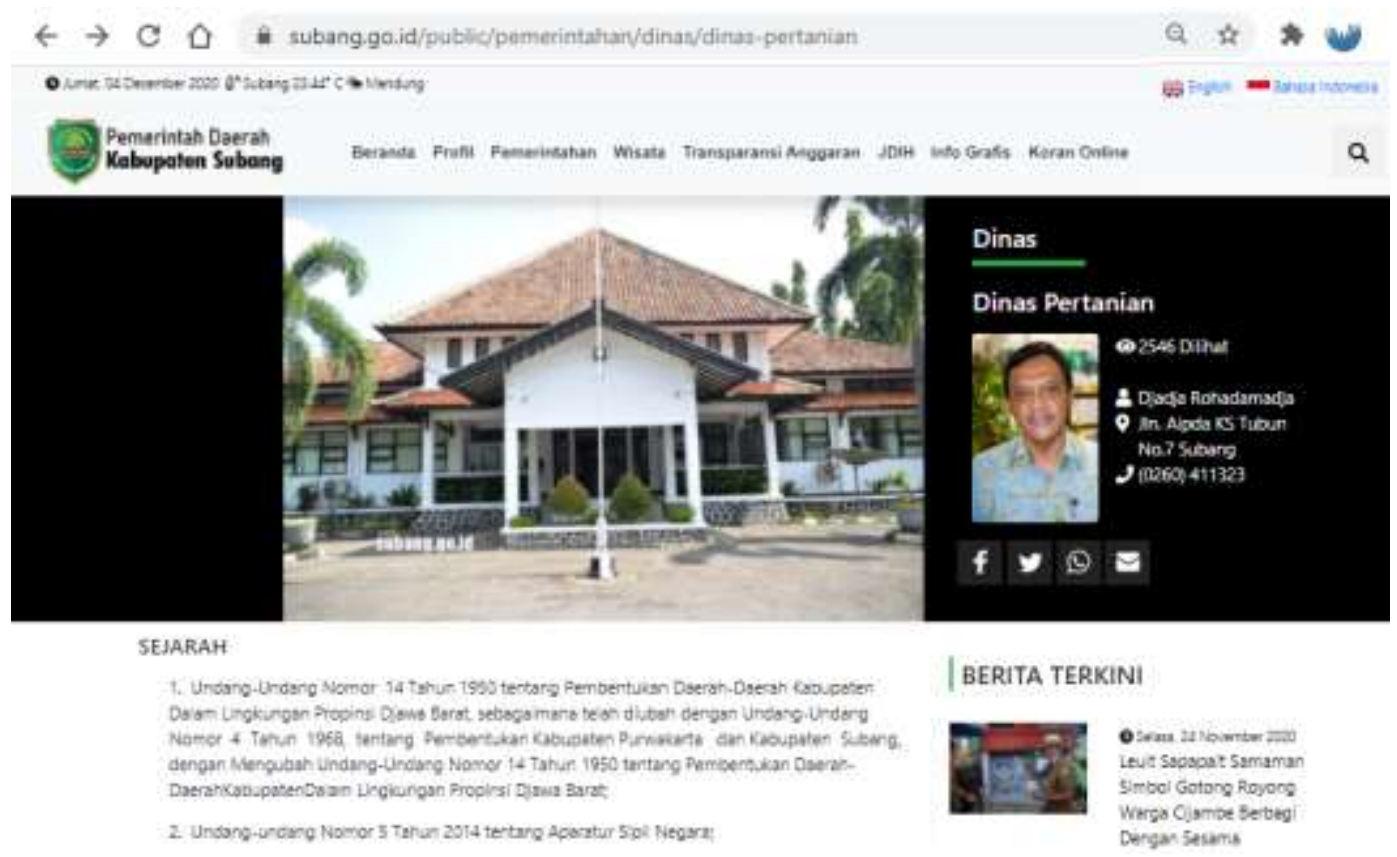

Gambar 1.1. Website Dinas Pertanian Kabupaten Subang

Kemudian permasalahannya dapat diidentifikasi sebagai berikut: belum adanya sistem informasi laporan produksi padi, pembuatan laporan masih dilakukan secara tersendiri atau terpisah. Dan tujuan dari penelitian ini adalah untuk melengkapi dinas pertanian dalam menyampaikan informasi terkait di bidangnya. Manfaat penelitian adalah dapat mengetahui sejauh mana kelengkapan informasi kantor dinas pertanian Subang.

Sebagai contoh dari data awal suatu lokasi di kecamatan Serangpanjang yang melingkupi 5 desa, yakni Cipancar, Cikujang, Cijengkol, Cintamekar, Ponggang, Talagasari. Berdasarkan data luas panen per hektar di tahun 2019 menunjukkan sebaran hasil produksi panen per hektar dan capaian produktivitasnya.

Tabel 1.1 Luas Panen, Hasil Per Hektar dan Produksi Padi Sawah di Kecamatan Serangpanjang Tahun 2019

\begin{tabular}{|c|c|c|c|}
\hline Desa & $\begin{array}{l}\text { Luas Panen } \\
\text { (Ha) }\end{array}$ & $\begin{array}{c}\text { Hasil Per } \\
\text { Hektar } \\
(\text { Ton/Ha) }\end{array}$ & $\begin{array}{c}\text { Produksi } \\
\text { (Ton) }\end{array}$ \\
\hline [1] & [2] & [3] & [4] \\
\hline 001 CIPANCAR & 286 & 5,19 & 1484,34 \\
\hline 002 CIKUJANG & 221 & 4,0 & 884 \\
\hline 003 CIJENGKOL & 257 & 4,90 & 1259,3 \\
\hline 004 CINTAMEKAR & 117 & 2,09 & 224,53 \\
\hline 005 PONGGANG & 385 & 7,1 & 2740,6 \\
\hline 006 TALAGASARI & 140 & 2,70 & 378 \\
\hline Jumlah & 1.406 & 25.98 & $6,970.77$ \\
\hline
\end{tabular}

Sumber : BP3K Kecamatan Serangpanjang 
Penelitian ini menggunakan pendekatan metode kuantitatif. Metode kuantitatif adalah bentuk penelitian yang dilakukan secara sistematis, terstruktur, serta terperinci. Pada pelaksanaaannya, metode riset ini fokus pada penggunaan angka,tabel,grafik, dan diagram untuk menampilkan hasil data/ informasi yang diperoleh.

Sistem Informasi adalah sekumpulan data yang terorganisasi beserta tatacara penggunaanya yang mencangkup lebih jauh dari pada sekedar penyajian. Istilah tersebut menyiratkan suatu maksud yang ingin dicapai dengan jalan memilih dan mengatur data serta menyusun tatacara penggunaanya. Keberhasilan suatu sistem informasi yang diukur berdasarkan maksud pembuatanya tergantung pada tiga faktor utama, yaitu keserasian dan mutu data, pengorganisasian data, dan tatacara penggunaanya. Untuk memenuhi permintaan penggunaan tertentu, maka struktur dan cara kerja sistem informasi berbeda-beda ber gantung pada keperluan atau jenis permintaan yang harus dipenuhi. Pada prinsipnya bahwa sistem informasi menggabungkan berbagai ragam data yang dikumpulkan dari berbagai sumber.

Data yang dipasok dari berbagai sumber dengan format yang beragam sebaiknya dilakukan transformasi menjadi bentuk data yang kompatibel.

Sistem informasi adalah suatu sistem di dalam suatu organisasi yang mempertemukan kebutuhan pengolahan transaksi harian yang mendukung fungsi operasi organisasi yang bersifat manajerial dengan kegiatan strategi dari suatu organisasi untuk dapat menyediakan kepada pihak luar tertentu dengan laporan-laporan yang diperlukan.[6]

Berdasarkan pendapat-pendapat di atas dapat disimpulkan bahwa sistem informasi adalah sekumpulan prosedur organisasi yang dilaksanakan untuk mencapai suatu tujuan yaitu memberikan informasi bagi pengambil keputusan dan untuk mengendalikan organisasi.Informasi dalam lingkup sistem informasi memiliki beberapa ciri yaitu: baru, informasi yang didapat sama sekali baru dan segar bagi penerima, tambahan, informasi dapat memperbaharui atau memberikan tambahan pada informasi yang telah ada, korektif adalah informasi dapat menjadi suatu koreksi atas informasi yang salah sebelumnya, penegas, informasi dapat mempertegas informasi yang telah ada.

Sistem adalah sekumpulan unsur/elemen yang saling berkaitan dan saling mempengaruhi dalam melakukan kegiatan bersama untuk mencapai suatu tujuan. Asal kata sistem berasal dari bahasa latin yaitu Systema dan bahasa Yunani yaitu Sustem. Sistem adalah sekumpulan unsur atau elemen-elemen yang saling berhubungan dan saling mempengaruhi dalam melakukan kegiataun bersama untuk mencapai tujuan yang sama. Sistem juga merupakan bagian terpenting dalam perkembangan ilmu pengetahuan sehingga banyak para ahli mengalihkan perhatian kepada pembelajaran mengenai sistem.

Mendefinisikan sistem secara umum sebagai kumpulan dari elemen-elemen yang berinteraksi untuk mencapai suatu tujuan tertentu sebagai satu kesatuan. Sistem adalah kumpulan elemen yang saling berhubungan dan berinteraksi dalam satu kesatuan untuk menjalankan suatu proses pencapaian suatu tujuan utama.Sistem juga merupakan bagian terpenting dalam perkembangan ilmu pengetahuan sehingga banyak para ahli mengalihkan perhatian kepada pembelajaran mengenai sistem.Dari uraian diatas dijelaskan bahwa sistem menunjukan kepada suatu objek metode atau tata cara pada suatu rencana metode, dan suatu alat untuk mencapai suatu tujuan. Sistem adalah suatu sarana yang menguasai keadaan pekerjaan agar dalam menjalankan tugas dapat diatur, dan sistem adalah suatu tatanan dari hal hal yang paling berkaitan dan berhubungan sehingga membentuk satu kesatuan dan satu keseluruhan.[7]

Website merupakan halaman situs sistem informasi yang dapat diakses secara cepat. Website ini didasari dari adanya perkembangan teknologi informasi dan komunikasi. Melalui perkembangan teknologi informasi, tercipta suatu jaringan antar komputer yang saling berkaitan. Internet menyediakan layanan termasuk e-mail, transmisi file, dan komunikasi dua arah antar individu atau komputer. Informasi melalui internet saat ini sudah menjadi kebutuhan khususnya bagi para petani dan dinas pertanian dalam membangun informasi khususnya di kabupaten Subang. Dengan layanan melalui informasi website dinas pertanian secara mudah dapat disebar ke para pengguna informasi yakni para petani bahkan juga pengguna lain secara umum.

Penelitian kuantitatif (quantitative research) adalah proses mengumpulkan dan menganalisis data numerik. Ini dapat digunakan untuk menemukan pola dan rata-rata, membuat prediksi, menguji hubungan sebab akibat, dan menggeneralisasi hasil ke populasi yang lebih luas. Penelitian kuantitatif adalah kebalikan dari penelitian kualitatif, yang melibatkan pengumpulan 
dan analisis data non-numerik (misalnya teks, video, atau audio). Penelitian kuantitatif banyak digunakan dalam ilmu alam dan sosial: biologi, kimia, psikologi, ekonomi, sosiologi, pemasaran, dan lain-lain.

Konsepsi penelitian kuantitatif ialah "berdasarkan jumlah atau banyaknya". Penelitian ialah "kegiatan pengumpulan, pengolahan, analisis, dan penyajian data yang dilakukan secara sistematis dan objektif untuk memecahkan suatu persoalan atau menguji suatu hipotesis untuk mengembangkan prinsip-prinsip umum." Cohen dan Manion mengatakan bahwa penelitian kuantitatif ialah penelitian sosial yang menggunakan metode-metode dan pernyataan-pernyataan empiris. Pernyataan empiris merupakan pernyataan deskripsif tentang "apa itu kasus" di "dunia nyata" dari apa yang "seharusnya" terjadi (Manion, 1980). Biasanya, pernyataan-pernyataan empiris dinyatakan dalam bentuk angka[5].

Studi Pustaka merupakan kegiatan menelusuri literatur yang ada serta menelaahnya secara tekun. Dengan mengadakan survey terhadap data yang telah ada, peneliti harus mencarai teoriteori yang telah berkembang dalam bidang ilmu yang diteliti, mencari metode-metode serta teknik penelitian, baik dalam pengumpulan data atau dalam analisa data yang pernah dilakukan oleh peneliti-peneliti terdahulu.[3]

\section{Analisa dan Pembahasan}

Tahapan pengumpulan data dilakukan dengan wawancara langsung dengan dinas pertanian kabupaten Subang. Menurut referensi tentang wawancara atau komunikasi : "Komunikasi 2 (dua) arah untuk mendapatkan data dari responden".[4]

Tahapan analisa mengurai data-data terkait kondisi saat ini dalam produktivitas hasil tanaman padi di kabupaten Subang. Untuk memahami perbedaan antara produktivitas dan produksi tanaman padi adalah sebagai berikut : misal terdapat 6 petani yang masing-masing telah menghasilkan gabah kering panen dari sampel hasil ubinan : bapak $\mathrm{A}=6,05 \mathrm{~kg}$, bapak $\mathrm{B}=4,8 \mathrm{~kg}$, bapak $\mathrm{C}=4,5 \mathrm{~kg}$, bapak $\mathrm{D}=4,2 \mathrm{~kg}$, bapak $\mathrm{E}=4,4 \mathrm{~kg}$, dan bapak $\mathrm{F}=5,8 \mathrm{~kg}$. Setelah dihitung, didapatkan hasil rata-rata ubinan 6 orang petani sebesar 6,6 ton/ha gabah kering panen (GKP). Maka hasil rata-rata ubinan 6 orang petani itu disebut produktivitas hasil panen di suatu lokasi. Sementara capaian hasil panen per petani disebut produksi hasil panen. Secara hitung-hitungan analisa data hasil panen akan dipengaruhi oleh luas lahan, luas tanam dan luas panen. Dinas pertanian kabupaten Subang tentu memetakan setiap kecamatan yang ada.

Tahapan selanjutnya dalam membangun perangkat lunak adalah pemodelan analisis. Pemodelan analisis yang dibuat adalah pendekatan objek. Usecase diagram adalah menunjukkan perilaku sistem yang akan dibuat. Penelitian ini hanya menggambarkan global dari sistem sehingga cukup menampilkan usecase diagram saja, dengan asumsi diagram-diagram berikutnya yang diperlukan tinggal menyesuaikan dengan usecase diagram.

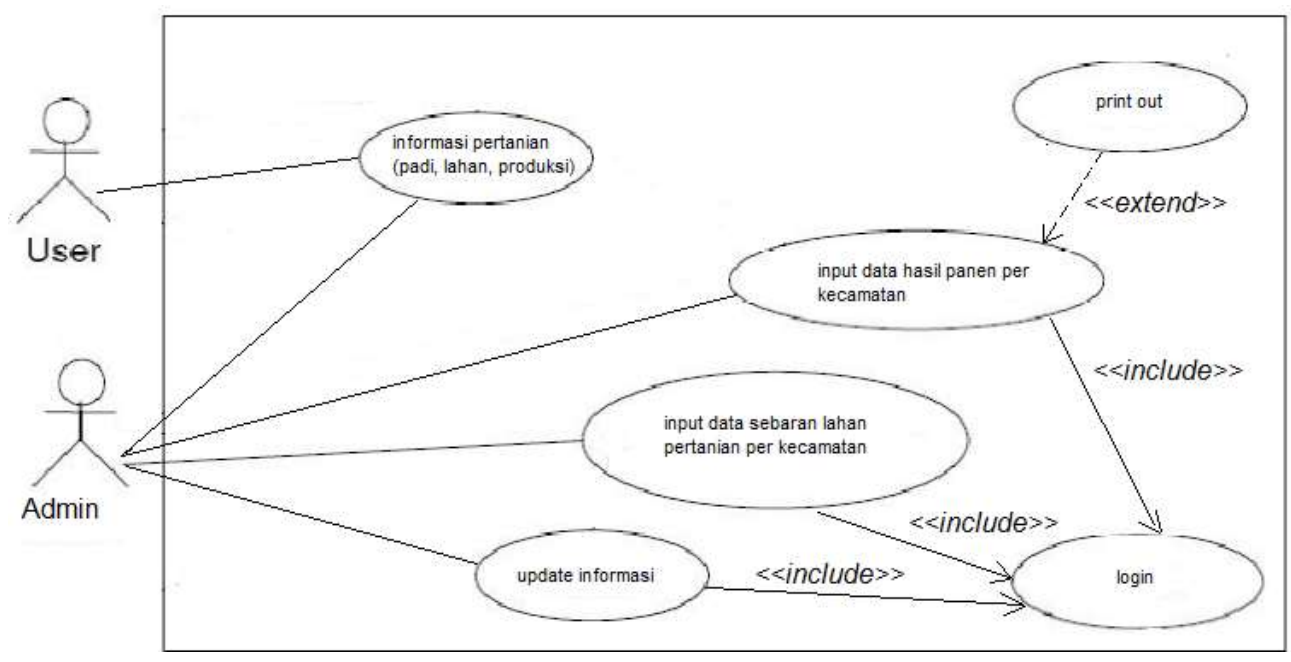

Gambar 2.1 Pemodelan Analisis 
Tahap awal dalam perancangan diantaranya merancang antarmuka (interface) untuk input data sebagai bahan masukan awal untuk menghitung capaian hasil panen secara keseluruhan. Interface untuk input data meliputi : nama kecamatan, luas lahan, luas tanam, luas panen, produktivitas, dan produksi. Setelah rancangan antarmuka kemudian diikuti rancangan struktur data maupun database berikut tabel-tabelnya. Rancangan interface seperti terlihat berikut ini:

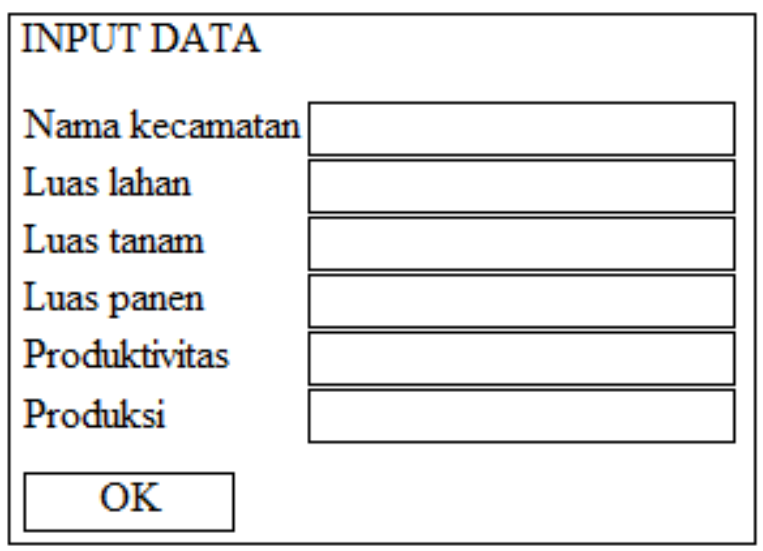

Gambar 2.2. Rancangan Input Data Tanaman Padi

Desain Database yang disusun adalah melibatkan tabel user_role, user_menu, user token, kecamatan, user sub_menu, tb_input, user_access_menu.

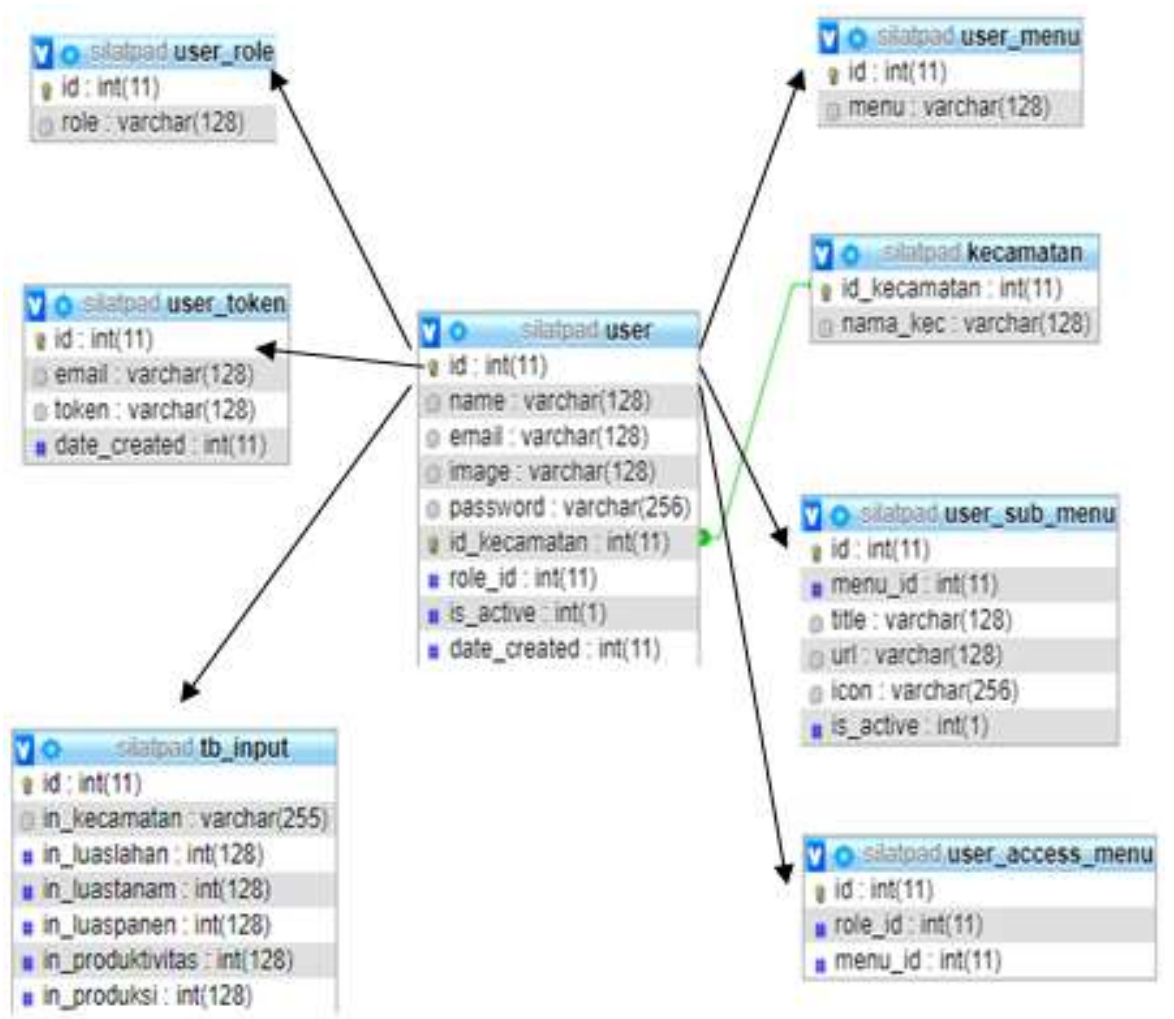

Gambar 2.3. Design Database 
Hak Akses merupakan previlidge adalah hak istimewa dari pengakses network system, dimana terdapat tingkatan-tingkatan akses ( user, guest, administrator). Hak Pengguna / Grup: Hak dasar: mengakses komputer dari jaringan, file / direktori cadangan, mengubah waktu sistem, masuk secara lokal, mengelola audit dan keamanan, log (penampil acara), memulihkan file dan direktori, mematikan sistem, mengambil file kepemilikan atau objek lain, dll. Hak berikutnya (advance): mengakses layanan dan kernel untuk kebutuhan sistem.

Secara sederhana gambaran hak akses dalam penelitian ini dimana menggambarkan hak akses dari sistem informasi tanaman padi di Dinas Pertanian Kabupaten Subang :

\begin{tabular}{|l|c|c|c|}
\hline \multicolumn{1}{|c|}{ Uraian } & Petugas & Admin & Pengunjung \\
\hline Form Input Anggota & - & yes & - \\
\hline Form Input Petugas & - & yes & - \\
\hline Form Input Data & yes & yes & - \\
\hline Form Edit Profile & yes & yes & yes \\
\hline Form Cetak Laporan & - & yes & - \\
\hline Menu Admin & - & yes & - \\
\hline Menu User & yes & yes & yes \\
\hline Menu Management & - & yes & - \\
\hline
\end{tabular}

Gambar 2.4. Table Hak Akses

Arsitektur sistem berbasis web terdiri dari user/petani (farmer), dinas pertanian (departemen of agriculture) website, internet, server (database) dapat dilihat pada gambar di bawah ini :

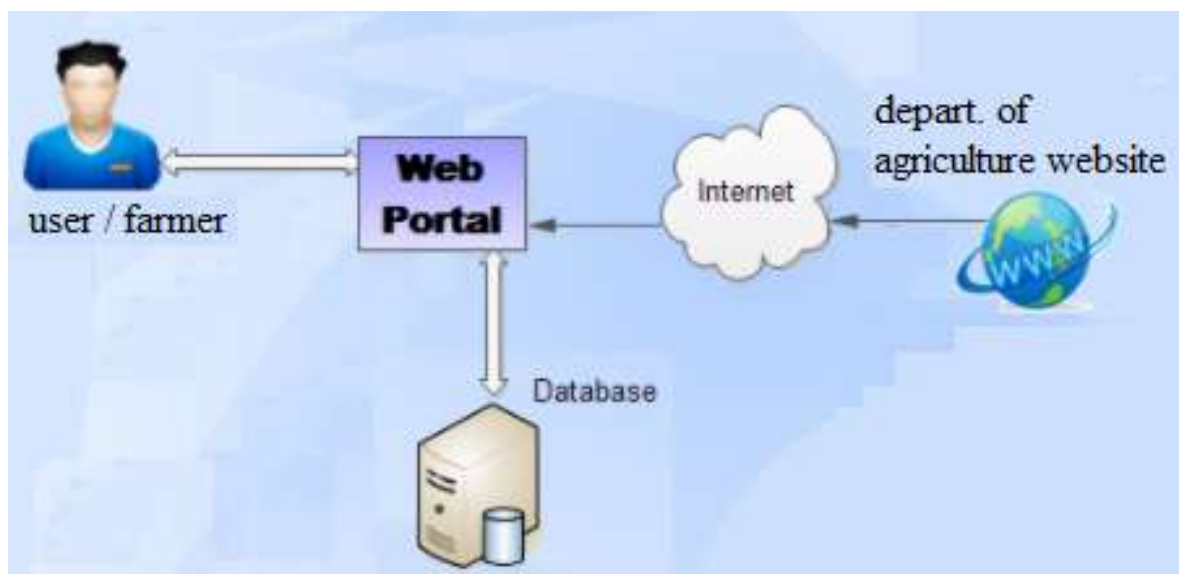

Gambar 2.4 Arsitektur sistem berbasis web

\section{Hasil}

Sebagai implementasi dari penelitian ini dimana pemanfaatan sistem informasi laporan produksi tanaman padi adalah sebagai bentuk upaya membantu petugas untuk mempermudah jalannya alur laporan yang sehingga mempercepat pengiriman informasi ke pusat, sekaligus dalam pembuatan laporan.

Maka penjelasan rinci dari setiap tampilan (interface) program aplikasi sistem terdiri dari halaman login, halaman registrasi, halaman utama. Halaman Login merupakan halaman yang 
menampilkan isian berupa email dan password, ini adalah jalan masuk satu-satunya untuk mengindentifikasi pengguna sebelum bisa menggunakan aplikasi ini. Kemudian diikuti halaman

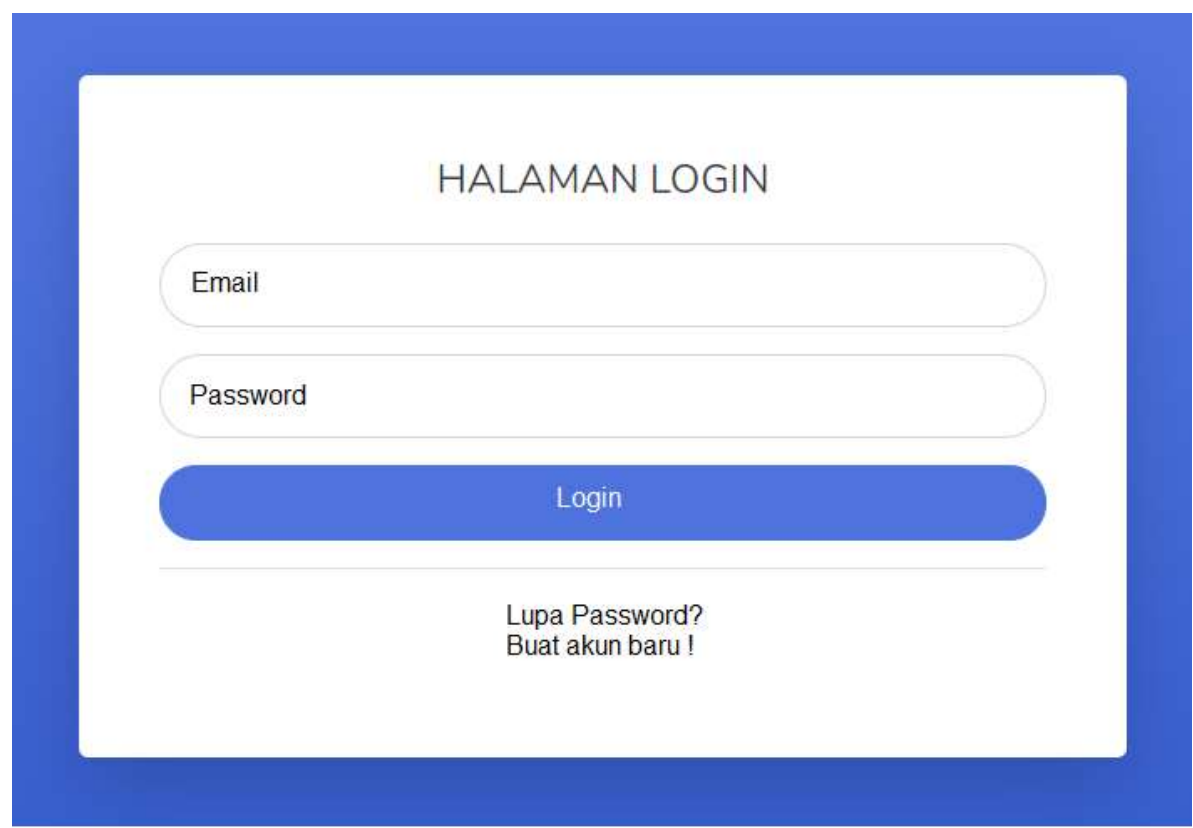

Gambar 3.1.Halaman Login

registrasi, dimana merupakan halaman yang berfungsi sebagai pembuatan akun (account) untuk bisa menggunakan aplikasi ini, seperti terlihat di bawah ini :

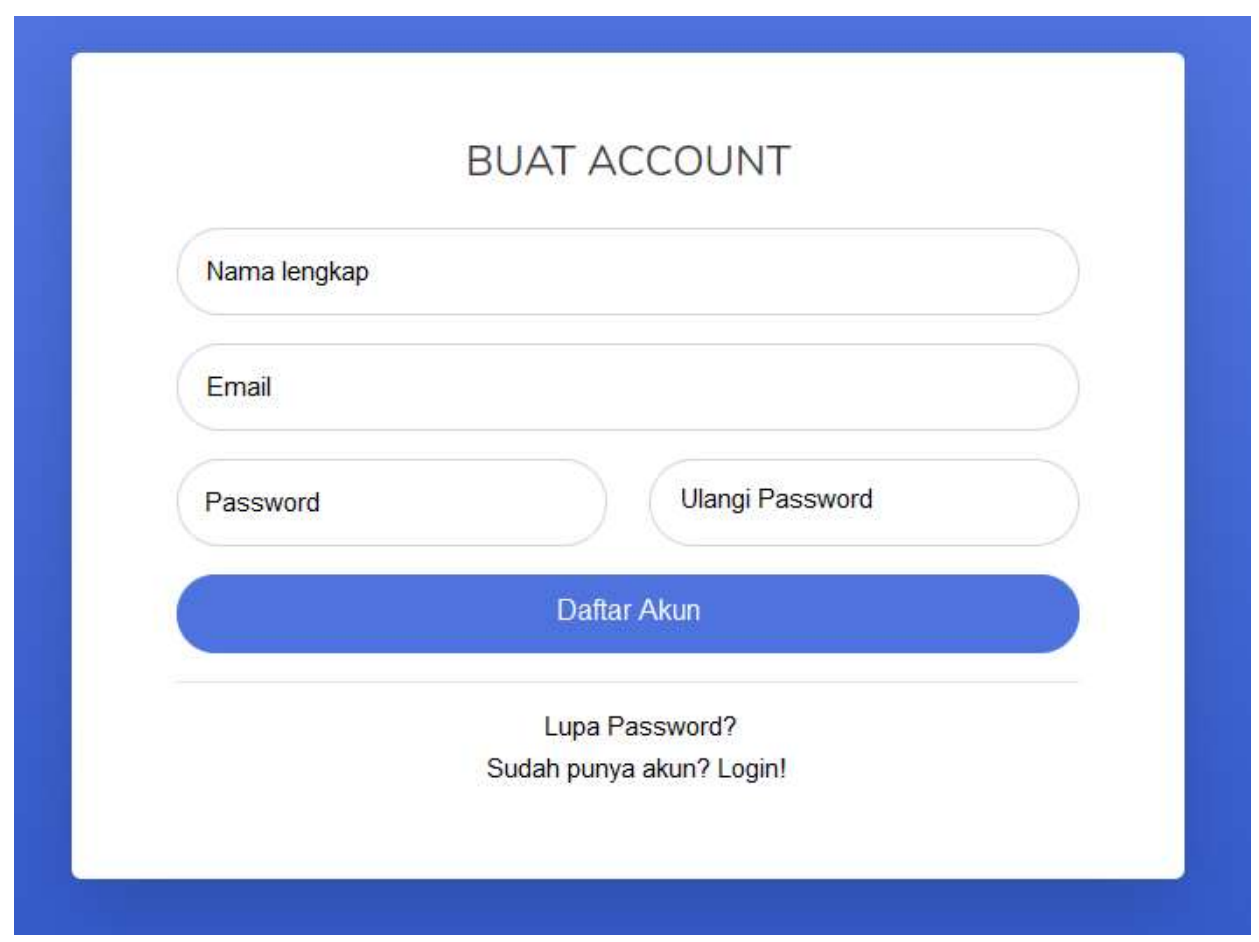

Gambar 3.2. Halaman Registrasi 
Dan yang paling terlihat secara keseluruhan adalah halaman utama (dashboard), sebagai halaman utama aplikasi, disaat user, petugas dan user pertama kali masuk akan melewati halaman ini, halaman dashboard digunakan untuk mempermudah pengguna untuk memonitoring perkembangan dalam bentuk grafik dan memilih disamping nya terlihat menu-menu yang tersedia.

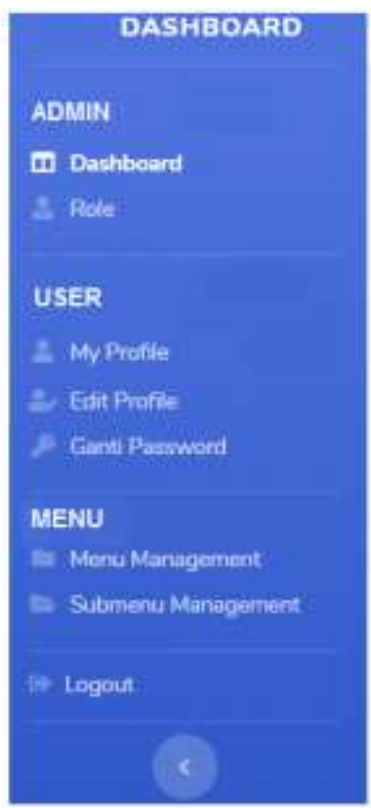

\section{Dashboard}

Gambar 3.3. Halaman Utama

Menu yang tersedia di dalam aplikasi, terdiri dari Tab Menu Admin, Tab Menu User, Tab Menu Management, dan tombol logout untuk keluar dari aplikasi jika sudah selesai melakukan pekerjaan.

My Profile

Nama

Kecamatan

Jabatan

NIP

No. Telp/HP

Gambar 3.4 Menu My Profile 


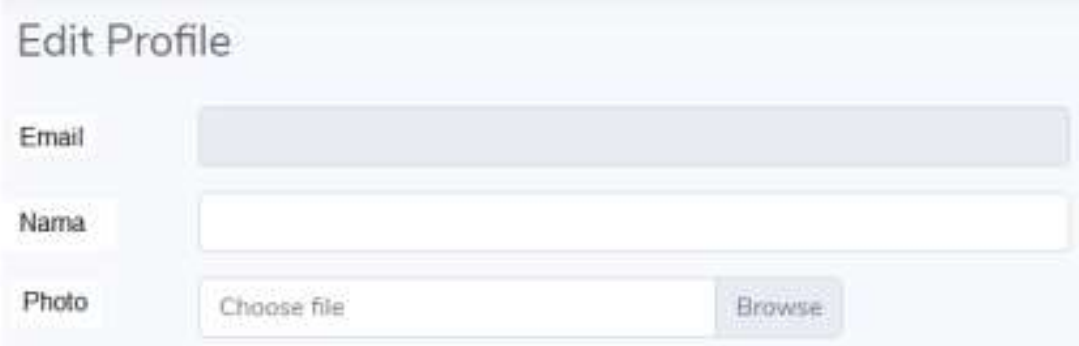

Gambar 3.5. Menu Edit Profil

Ganti Password
Password saat ini
Password baru
Ulangi password
Ganti Password

Gambar 3.6. Menu Ganti Password

Rancangan website tampilan untuk informasi rincian laporan hasil produksi padi secara keseluruhan yang meliputi semua kecamatan di kabupaten Subang seperti terlihat di bawah ini :

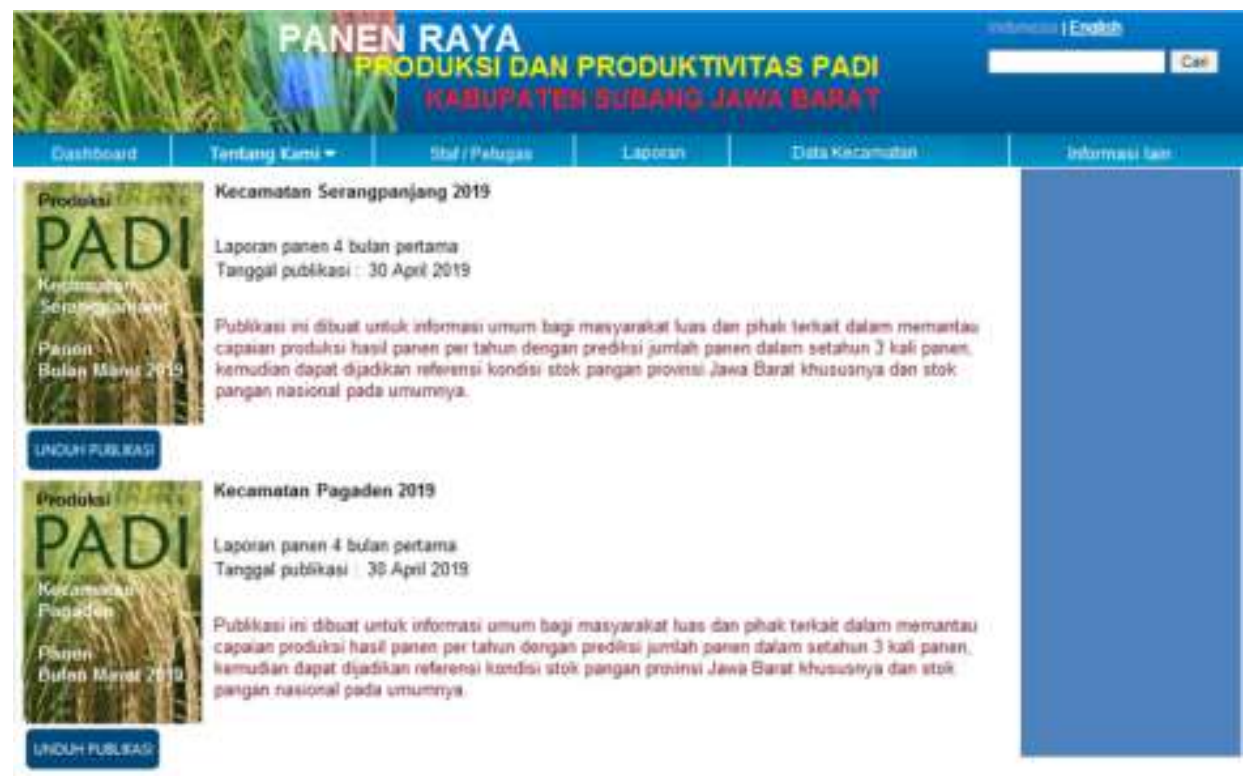

Gambar 3.7. Rancangan Website Informasi Produksi Padi 


\section{Kesimpulan}

Berdasarkan permasalahan yang telah dibahas dan diselesaikan melalui laporan ini, maka terdapat beberapa kesimpulan antara lain bahwa sistem informasi ini memudahkan petugas dalam pengelolaan data laporan perkembangan tanaman padi dan penyusunan laporan dinas, cara penggunaan system informasi mudah digunakan oleh orang awam, karena aturan yang digunakan mudah dimengerti oleh pengguna.

Dan sebagai masukan /saran untuk peneliti berikutnya adalah perlu pengembangan sistem informas; adanya pengembangan ruang lingkup sistem lebih lanjut, misalnya pengembangan menu-menu baru, pengembangan sistem dengan menggunakan mobile system sehingga penggunaannya lebih fleksibel.

\section{Daftar Pustaka}

[1] Badan Pusat Statistik .2019. Produksi Tanaman Padi Seluruh Provinsi. http://bps.tnmnpgn.go.id. Diakses tanggal 20Desember 2019

[2] Dinas Pertanian Kabupaten Subang, 2016-2019. Data Pertanaman Komoditi Tanaman Padi Kabupaten Subang

[3] Hendiyanto Achmad, Arham Zainul, Khudzaeva Eva, Rancang Bangun Sistem Informasi Spasial Persebaran Peternakan Berbasis Web (Studi Kasus : Kota Depok), Vol 10, No 2 (2017), https://doi.org/10.15408/sijsi.v10i2.7757

[4] Jogiyanto. 2008. Metodologi Penelitian Sistem Informasi. CV Andi Offset. Yogyakarta

[5] Nikolaus Duli, Metodologi Penelitian Kuantitatif : Beberapa konsep dasar untuk penulisan skripsi \& analisis data dengan SPSS, ISBN elektronik : 978-623-02-0550-7, Deeppublish 2019

[6] Subtari Tata, 2016, Sistem Informasi Manajemen, Andi Offset, Yogyakarta

[7] Sutarman, 2012, "Buku Pengantar Teknologi Informasi”, Jakarta, Bumi Aksara 